\title{
Soft hydrothermal synthesis of hafnon, $\mathrm{HfSiO}_{4}$
}

\author{
Paul Estevenon ${ }^{\dagger, \ddagger}, \AA$, , Thibault Kaczmarek ${ }^{\dagger, \ddagger}$, Mohamed Ruwaid Rafiuddin ${ }^{\ddagger}$, Eleonore Welcomme ${ }^{\dagger}$, \\ Stephanie Szenknect ${ }^{\star}$, Adel Mesbah ${ }^{\star}$, Philippe Moisy ${ }^{\dagger}$, Christophe Poinssot $^{\dagger}$, Nicolas Dacheux ${ }^{*}$, \\ ${ }^{\dagger}$ CEA, DEN, DMRC, Univ Montpellier, Marcoule, France. \\ * ICSM, Univ Montpellier, CNRS, CEA, ENSCM, Marcoule, France. \\ KEYWORDS: hafnium silicate, hafnon, wet chemistry route, hydrothermal synthesis, zircon structure type.
}

\begin{abstract}
Despite being a member of the zircon type silicate family, the conditions allowing the hydrothermal synthesis of $\mathrm{HfSiO}_{4}$ were not well constrained. A multiparametric study was performed in order to follow the synthesis of this phase under soft hydrothermal conditions and thus to determine the most efficient conditions to form single phase samples. Among the experimental parameters investigated, concentration of reactants, $\mathrm{pH}$ of the reactive media, temperature and duration of the hydrothermal treatment impacted significantly the formation rate of hafnon and its crystallization state. Pure $\mathrm{HfSiO}_{4}$ was obtained in acid reactive media with an acidity ranging from $\mathrm{C}_{\mathrm{HCl}}=1.5 \mathrm{M}$ to $\mathrm{pH}=1.0$ and for $\mathrm{C}_{\mathrm{Si}} \approx \mathrm{C}_{\mathrm{Hf}} \geq 0.21 \mathrm{~mol} \cdot \mathrm{L}^{-1}$. The silicate phase was obtained after a 24-hours treatment at temperatures ranging from $150^{\circ} \mathrm{C}$ to $250^{\circ} \mathrm{C}$. However, the rise of temperature and extension of the duration of the hydrothermal treatment favored the crystallization state of the final $\mathrm{HfSiO}_{4}$ samples. $^{2}$
\end{abstract}

\section{INTRODUCTION}

Hafnon, $\mathrm{HfSiO}_{4}$, is one of the end-members belonging to the zircon-type silicate group (tetragonal, I41/amd) like $\mathrm{ZrSiO}_{4}$, $\mathrm{CeSiO}_{4}, \quad \mathrm{ThSiO}_{4}, \mathrm{PaSiO}_{4}, \quad \mathrm{USiO}_{4}, \quad \mathrm{NpSiO}_{4}, \quad \mathrm{PuSiO}_{4}$ and $\mathrm{AmSiO}_{4} \cdot{ }^{1,2-4}$ As a consequence, hafnon is reported to form a solid solution with $\mathrm{ZrSiO}_{4}{ }^{5-7}$ It is usually observed as a minor component in natural zircons ${ }^{8-10}$ and less frequently as the major phase in natural assemblies where zircon appears as a minor secondary phase. ${ }^{11}$

Owing to its interesting thermal and electric properties (such as thermal shock resistance, low dilatation coefficient on a wide temperature range, high thermal conductivity, low relative permittivity and low dielectric loss), ${ }^{12,13}$ hafnon is often considered as promising high-temperature refractory material 12 for semiconductor devices ${ }^{14}$ or microwave substrate for electronic data transmission. ${ }^{13}$

Moreover, as zircon-type ceramics (e.g. $\mathrm{ZrSiO}_{4}$ and $\mathrm{HfSiO}_{4}$ ) are isostructural with actinide silicates, $\mathrm{An}^{\mathrm{IV}} \mathrm{SiO}_{4}$ and due to its high chemical stability, they have been suggested as potential actinide-specific matrices for the immobilization of radionuclides associated to high level nuclear waste and more specifically of plutonium excess coming from dismantled nuclear weapons. ${ }^{15-19}$ In this context, $(\mathrm{Hf}, \mathrm{Pu}) \mathrm{SiO}_{4}$ compounds were prepared by Burakov et al. using sol-gel method. ${ }^{20}$ However, these experiments suggest that plutonium content cannot exceed $7 \mathrm{wt} \%$ in such materials.

From a general point of view, the synthesis of $\mathrm{HfSiO}_{4}$ was reported by high temperature solid state chemistry, $1,5,7,13,21-25$ sol-gel methods, ${ }^{12,26,27}$ chemical transport reaction, ${ }^{14,} 28,29$ physical vapor deposition ${ }^{30}$ and hydrothermal synthesis. ${ }^{31,32}$ However, the only hydrothermal syntheses were reported by Caruba et al. under acid conditions at $\mathrm{T}=800^{\circ} \mathrm{C}, 75 \mathrm{MPa},{ }^{31}$ and by McNeil et al. in very acid conditions, i.e. $\mathrm{C}_{\mathrm{HF}}=6 \mathrm{~mol} \cdot \mathrm{L}^{-1}$ and $\mathrm{C}_{\mathrm{H} 2 \mathrm{SO} 4}=0.5 \mathrm{~mol} \cdot \mathrm{L}^{-1}$ at $\mathrm{T}=850^{\circ} \mathrm{C}$,
$200 \mathrm{MPa}^{32}$ These conditions appear to be quite surprising taking into account the possibility to prepare isostructural silicates, e.g. $\mathrm{ZrSiO}_{4}$, ${ }^{31,}{ }^{33-46} \mathrm{CeSiO}_{4}{ }^{4},{ }^{47-49} \mathrm{ThSiO}_{4}{ }^{2}$, 34, 50-65 $\mathrm{USiO}_{4}{ }^{2}$, $59,60,66-76 \mathrm{NpSiO}_{4}{ }^{2} \mathrm{PuSiO}_{4}{ }^{2}$ and $\mathrm{AmSiO}_{4}{ }^{2}$ under soft hydrothermal conditions (i.e. for $\mathrm{T} \leq 250^{\circ} \mathrm{C}$ ). However, it may be also noticed that the formation of amorphous hafnon has been observed by alteration, in aqueous solution, of Hfbearing borosilicate glasses at $90^{\circ} \mathrm{C}$ and $\mathrm{pH}=1 .^{77}$ More specifically, we recently reported that modifications of the starting $\mathrm{pH}$ and elementary concentrations allowed to decrease the temperature of formation of $\mathrm{ThSiO}_{4}$ and $\mathrm{CeSiO}_{4}$ under hydrothermal conditions. ${ }^{49,64}$ Therefore, the aim of this study was to determine an efficient way of synthesis allowing the formation of $\mathrm{HfSiO}_{4}$ under soft hydrothermal conditions.

\section{MATERIALS AND METHODS}

\section{Syntheses}

All the reagents used for the materials preparation were supplied by Sigma-Aldrich. $\mathrm{Na}_{2} \mathrm{SiO}_{3} \cdot 5 \mathrm{H}_{2} \mathrm{O}(95 \%)$ and $\mathrm{HfCl}_{4}$ (98\%) were used as aqueous silicate and hafnium precursors, respectively. 1.5 and $1.0 \mathrm{~mol} \cdot \mathrm{L}^{-1} \mathrm{HCl}$ solutions were prepared by dilution of Sigma Aldrich ACS grade mother solutions $\mathrm{HCl}(37 \%) .8 \mathrm{~mol} \cdot \mathrm{L}^{-1} \mathrm{NaOH}$ solution was freshly prepared from Sigma Aldrich ACS grade $\mathrm{NaOH}(98 \%)$ before the experiments.

The syntheses of $\mathrm{HfSiO}_{4}$ were performed by adapting the protocol recently developed for $\mathrm{ThSiO}_{4}{ }^{64}$ Aqueous mixtures of hafnium at the oxidation state $+\mathrm{IV}$ and silicate were prepared by dissolving $\mathrm{HfCl}_{4}$ and $\mathrm{Na}_{2} \mathrm{SiO}_{3} \cdot 5 \mathrm{H}_{2} \mathrm{O}$ in $1.5 \mathrm{~mol} \cdot \mathrm{L}^{-1}$ hydrochloric acid (Table S1). At this stage, a silicate excess of 3 mol.\% was considered to avoid the formation of hafnium dioxide or hydroxides during the synthesis. The $\mathrm{pH}$ was then adjusted to the final value with $8 \mathrm{~mol} \cdot \mathrm{L}^{-1} \mathrm{NaOH}$.

All the prepared mixtures were introduced in a $23 \mathrm{~mL}$ Teflon lined container. The container was placed in a Parr auto- 
clave in an oven to reach hydrothermal conditions during 1 to 20 days with a given temperature and under autogenous pressure. The final cooling to room temperature was done within one hour. Then, the precipitates were separated from the supernatant by centrifugation at $14000 \mathrm{rpm}$ for $12 \mathrm{~min}$, washed twice with deionized water and once with ethanol. They were finally dried overnight at $60^{\circ} \mathrm{C}$ in an oven.

\section{Characterization}

PXRD data were collected on the resulting powders using the Bruker D8 advance diffractometer equipped with a lynxeye detector and working with $\mathrm{Cu} K \alpha$ radiation $(\lambda=1.54184 \AA)$ in a reflection geometry (parallel beam). Patterns were recorded between $5^{\circ}$ and $100^{\circ}(2 \theta)$ with steps of $0.019^{\circ}$ and a total counting time of 2.5 to 3 hours per sample. Pure silicon was used as a standard material to extract the instrumental function. The collected data were refined by the Rietveld method using the Fullprof_suite package. ${ }^{78}$ During the refinements, different profile and structure parameters were adjusted, such as the zero shift, unit-cell parameters, scale factor, and overall displacement factor. An anisotropic size and strain model was also used in order to consider the broadening effect.

Raman spectra were recorded with a Horiba-Jobin Yvon Aramis device equipped with an edge filter and a $\mathrm{Nd}$ :YAG laser $(532 \mathrm{~nm})$ that delivered $60 \mathrm{~mW}$ at the sample surface. In order to avoid any laser-induced degradation of the compound, the power was turned down by the means of optical filters. The laser beam was then focused on the sample using an Olympus BX 41 microscope with an $\times 50$ LMP objective, resulting in a spot area of $\sim 1 \mu^{2}$ and a power of $39 \mathrm{~mW}$. For each spectrum, a dwell time of 1 to $30 \mathrm{~s}$ was used. Four scans were recorded for each analyzed area in order to minimize the measurement error.

FTIR spectra were recorded with a Perkin-Elmer FTIR Spectrum 100 device in the $300-4000 \mathrm{~cm}^{-1}$ range. Powdered samples were deposited on the surface of an ATR crystal without any prior preparation. The spectra collected in such operating conditions exhibited a resolution lower than $4 \mathrm{~cm}^{-1}$. Four scans were performed to average the measurement error.

SEM observations were directly conducted using a FEI Quanta 200 electronic microscope on small powder samples without prior preparation such as metallization. The electronic microscope was equipped either with an Everhart-Thornley Detector (ETD) or a Back-Scattered Electron Detector (BSED), under high vacuum conditions with a low accelerating voltage $(8 \mathrm{kV})$. These conditions were chosen in order to create a beam deceleration effect that led to high resolution images.

Thermogravimetric analyses were performed to determine the hydration content of the samples prepared at the end of the syntheses. All of these analyses were done between room temperature and $1000^{\circ} \mathrm{C}$ under air atmosphere thanks to a SETSYS evolution analyzer. These measurements were coupled with mass spectroscopy analyses on the residual gaz.

\section{Effect of $\mathrm{pH}$ of the starting solution}

The effect of $\mathrm{pH}$ of the starting mixture on the nature of the resulting precipitate was followed between $\mathrm{C}_{\mathrm{HCl}}=1.5 \mathrm{~mol} \cdot \mathrm{L}^{-1}$ and $\mathrm{pH}=8$ considering a starting mixture with a hafnium concentration of $0.21 \mathrm{~mol} \cdot \mathrm{L}^{-1}$ and a Si:Hf molar ratio of 1.03 . Hydrothermal treatments were performed at $250^{\circ} \mathrm{C}$ during 24 hours.

All the samples prepared were characterized by PXRD (Figure 1). From these data, $\mathrm{HfSiO}_{4}$ (zircon-type structure, space group $\mathrm{I}_{1} / \mathrm{amd}$ ) was formed using a starting mixture whose acidity was below $\mathrm{pH}=1.6$. For higher $\mathrm{pH}$ values, the precipitation of monoclinic $\mathrm{HfO}_{2}$ (space group $\mathrm{P} 2{ }_{1} / \mathrm{c}$ ) was obtained due to hafnium hydrolysis leading to the precipitation of the hafnium hydroxides then hafnium oxide by ageing. In these conditions, the unit cell parameters of $\mathrm{HfSiO}_{4}$ reached $a=6.596(2) \AA$ and $c=5.958(3) \AA$ (i.e. V = 259.2(1) $\AA^{3}$; values calculated by averaging the data obtained on the samples (1) to (4) - syntheses leading to $\mathrm{HfSiO}_{4}$ as single phase). The $a$ and $c$ lattice parameters were slightly higher and smaller, respectively, than the reference lattice parameters obtained by high temperature methods $(a=6.5725$ (7) $\AA$ and $c=5.9632(4)$ $\AA$, i.e. $\left.V=257.60(7) \AA^{328}\right)$. According to the recent results already reported for $\mathrm{ThSiO}_{4}$, these variations were attributed to the insertion of hydroxide groups in the $\mathrm{HfSiO}_{4}$ structure ${ }^{64,79}$, which may be correlated to the non-ideal crystallization in the soft hydrothermal conditions considered.

Rietveld refinements performed on the PXRD data did not allow to observe any significant variation of the $\mathrm{HfSiO}_{4}$ unitcell parameters (Table 1) nor of the crystallite size (Figure S1 and Table 1 and Table S2) according to the initial $\mathrm{pH}$ of the reactive media.

Characterization by Raman and IR spectroscopies (Figure 2) revealed the presence of symmetric and antisymmetric stretching modes of $\mathrm{SiO}_{4}$ at $979 \mathrm{~cm}^{-1}$ and $1015 \mathrm{~cm}^{-1}$, respectively by Raman $\left(868 \mathrm{~cm}^{-1}\right.$ and $1054 \mathrm{~cm}^{-1}$, respectively by IR spectroscopy). The symmetric bending modes were observed at $451 \mathrm{~cm}^{-1}$. On the contrary, the antisymmetric mode was not observed due to its low intensity (both symmetric and antisymmetric modes were observed at $433 \mathrm{~cm}^{-1}$ and $627 \mathrm{~cm}^{-1}$, respectively by IR spectroscopy) (Table 2 ).

It worth noting that the positions of the $\mathrm{HfSiO}_{4}$ 's $v_{1}$ and $v_{3}$ vibration bands observed by infrared spectroscopy are significantly different to the ones reported in the literature (Table 2). However, the values obtained here are in great agreement with the ones reported in the literature for the other zircon type silicate phases (Table S3) and especially for $\mathrm{ZrSiO}_{4}\left(v_{1}=\right.$ $866 \mathrm{~cm}^{-1}$ and $\left.v_{3}=1049 \mathrm{~cm}^{-1}\right) .{ }^{80}$ Moreover, the position of the $v_{3}$ vibration bands at around $1050 \mathrm{~cm}^{-1}$ should be taken with care because this position correspond to the $v_{4}$ mode of $\mathrm{SiO}_{2}$.

Additionally, the presence of small amounts of hydroxide groups or water was suggested from the observation of broad bands around $3400 \mathrm{~cm}^{-1}$ and $1630 \mathrm{~cm}^{-1}$ in the IR spectra, which was consistent with the hypothesis proposed regarding the insertion of hydroxide groups in the $\mathrm{HfSiO}_{4}$ lattice already suggested from PXRD analyses.

\section{RESULTS AND DISCUSSION}




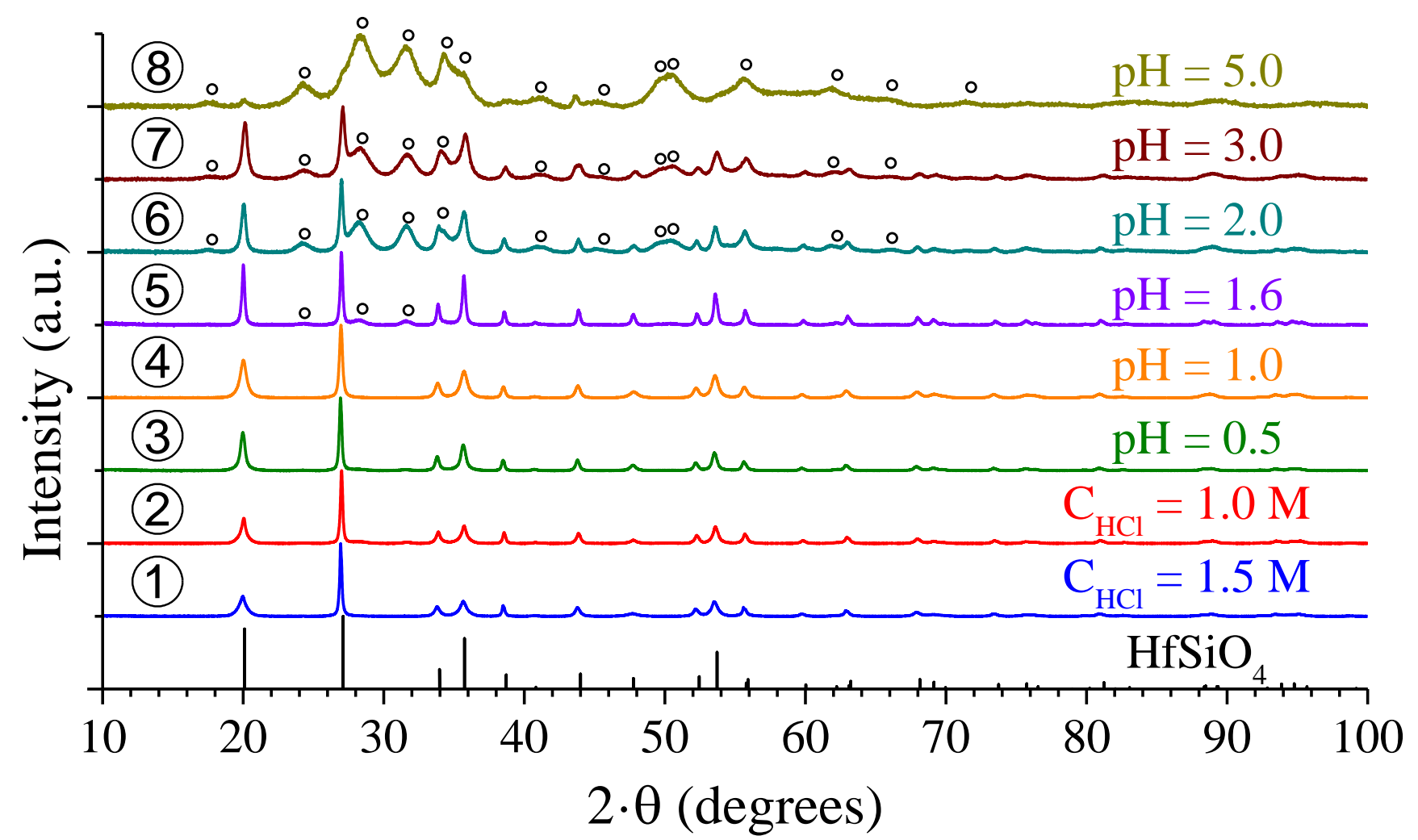

Figure 1. PXRD patterns recorded for samples prepared under hydrothermal conditions $\left(24\right.$ hours, $\left.\mathrm{T}=250^{\circ} \mathrm{C}\right)$ with hafnium and silicate concentrations of $0.21 \mathrm{~mol} \cdot \mathrm{L}^{-1}$ and for various initial $\mathrm{pH}$ values: $\mathrm{C}_{\mathrm{HCl}}=1.5 \mathrm{~mol} \cdot \mathrm{L}^{-1}(1), \mathrm{C}_{\mathrm{HCl}}=1.0 \mathrm{~mol} \cdot \mathrm{L}^{-1}(2), \mathrm{pH}=0.5(3)$, $\mathrm{pH}=1.0(4), \mathrm{pH}=1.6(5), \mathrm{pH}=2.0(6), \mathrm{pH}=3.0(7)$ and $\mathrm{pH}=5.0(8)$. Bragg positions of the characteristic peaks of hafnon were extracted from ${ }^{28}$. The presence of $\mathrm{HfO}_{2}$ is pointed out by empty circles in the PXRD patterns.

Table 1. Lattice parameters and crystallite size determined by Rietveld refinement for $\mathrm{HfSiO}_{4}$ samples.

\begin{tabular}{|c|c|c|c|c|}
\hline \multirow{2}{*}{ Label } & \multicolumn{3}{|c|}{ Unit cell parameters } & \multirow{2}{*}{ Crystallite size (nm) } \\
\hline & a $(\AA)$ & $c(\AA)$ & $V\left(\AA^{3}\right)$ & \\
\hline (1) & $6.5946(1)$ & $5.9605(1)$ & $259.22(1)$ & $20 \pm 11$ \\
\hline (3) & $6.5956(1)$ & $5.9561(1)$ & 259.11(1) & $24 \pm 7$ \\
\hline (4) & $6.5988(1)$ & $5.9544(1)$ & $259.27(1)$ & $22 \pm 8$ \\
\hline (6) & $6.5945(2)$ & $5.9583(2)$ & 259.11(1) & $27 \pm 2$ \\
\hline (7) & $6.5912(4)$ & $5.9555(4)$ & $258.73(3)$ & $15 \pm 1$ \\
\hline (8) & $6.594(2)$ & $5.947(3)$ & $258.6(2)$ & ND \\
\hline (9) & $6.5939(1)$ & $5.9542(1)$ & $258.89(1)$ & $381 \pm 237$ \\
\hline (10) & $6.5913(1)$ & $5.9602(1)$ & 258.94(1) & $88 \pm 14$ \\
\hline (14) & $6.5961(1)$ & $5.9611(1)$ & $259.36(1)$ & $31 \pm 6$ \\
\hline (15) & $6.5935(1)$ & $5.9606(1)$ & $259.13(1)$ & $80 \pm 18$ \\
\hline (3) after TGA & $6.5714(8)$ & $5.9685(11)$ & $257.74(7)$ & ND \\
\hline
\end{tabular}

ND : Not Determined 
(a)

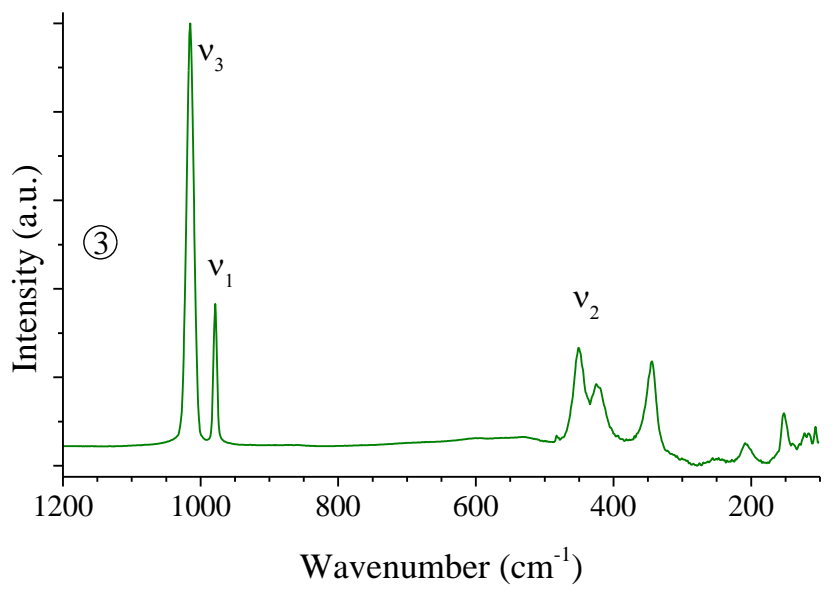

(b)

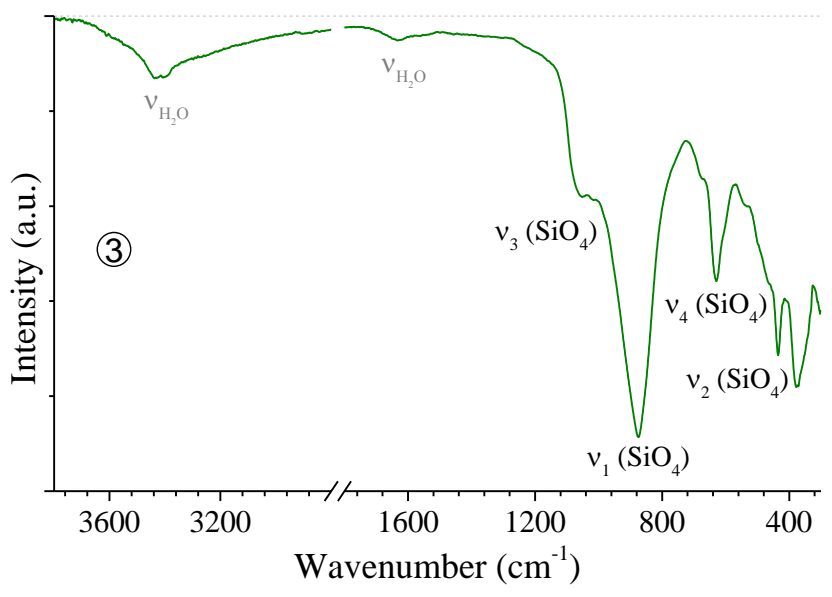

Figure 2. Raman (a) and IR (b) spectra recorded for $\mathrm{HfSiO}_{4}$ samples prepared under hydrothermal conditions during 24 hours at $\mathrm{T}=250^{\circ} \mathrm{C}$ starting from hafnium and silicate concentrations of $0.21 \mathrm{~mol} \cdot \mathrm{L}^{-1}$ and with $\mathrm{pH}=0.5(3)$.

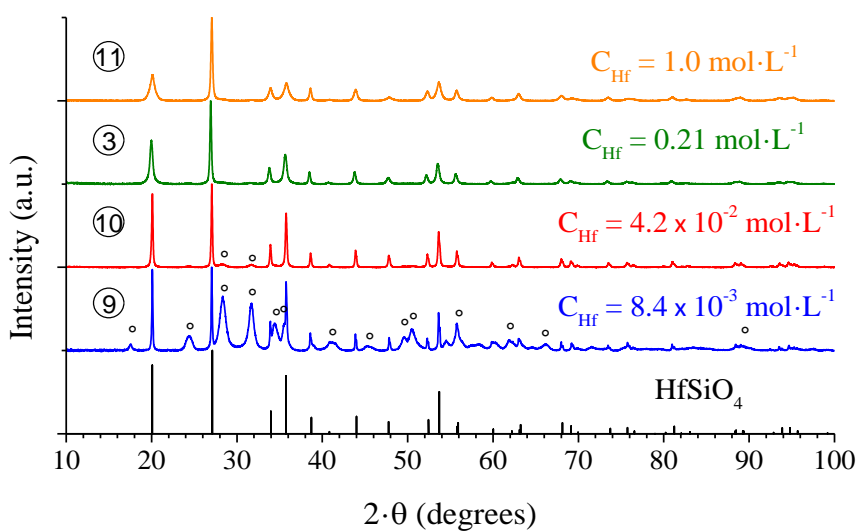

Figure 3. PXRD patterns recorded for samples prepared under hydrothermal conditions ( 24 hours, $\mathrm{T}=250^{\circ} \mathrm{C}$ ) with $\mathrm{pH}=0.5$ and various hafnium and silicate concentrations (with a molar ratio of $\mathrm{Si}: \mathrm{Hf}=1.03): \mathrm{C}_{\mathrm{Hf}}=8.4 \times 10^{-3} \mathrm{~mol} \cdot \mathrm{L}^{-1} \quad(9), \mathrm{C}_{\mathrm{Hf}}=4.2 \times 10^{-2}$ $\mathrm{mol} \cdot \mathrm{L}^{-1}(10), \mathrm{C}_{\mathrm{Hf}}=0.21 \mathrm{~mol} \cdot \mathrm{L}^{-1}(11)$ and $\mathrm{C}_{\mathrm{Hf}}=1.0 \mathrm{~mol} \cdot \mathrm{L}^{-1}(12)$. The characteristic Bragg positions of hafnon were extracted from ${ }^{28}$ and the XRD lines associated to $\mathrm{HfO}_{2}$ are pointed out by empty circles in the PXRD patterns.

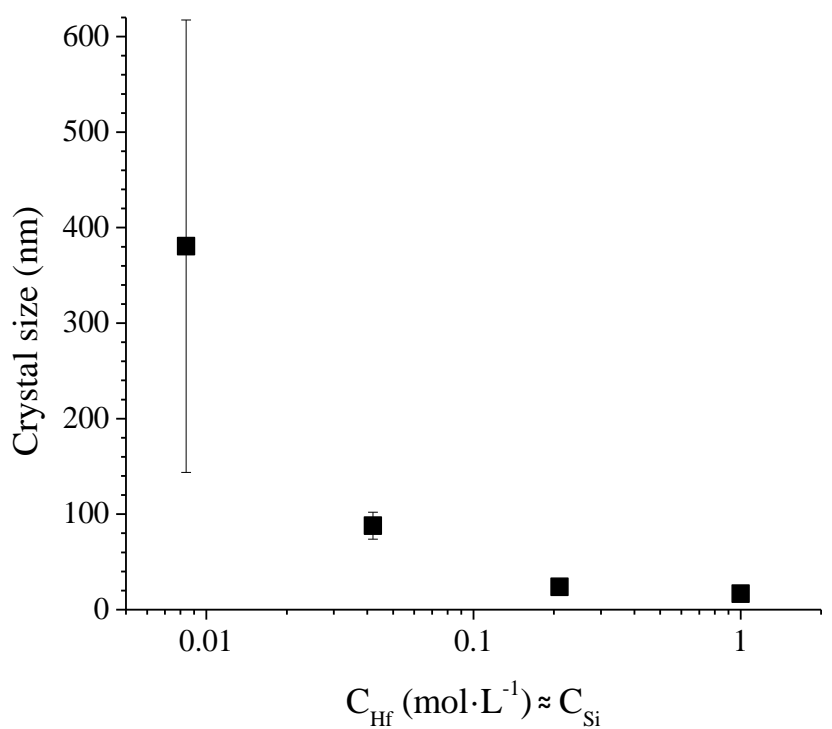

Figure 4. Variation of the $\mathrm{HfSiO}_{4}$ crystallite size determined by Rietveld refinement as a function of the starting hafnium and silicate concentrations, obtained for samples under hydrothermal conditions $\left(250^{\circ} \mathrm{C}, 24\right.$ hours $)$ and with $\mathrm{pH}=0.5$.

Table 2. Assignment of the vibration bands (expressed in $\mathrm{cm}^{-1}$ ) associated to silicate groups observed in the Raman and IR spectra of $\mathrm{HfSiO}_{4}$.

\begin{tabular}{ccccccccc}
\hline & \multicolumn{3}{c}{ Raman Spectroscopy } & \multicolumn{3}{c}{ Infrared spectroscopy } \\
& $v_{2}$ & $v_{4}$ & $v_{1}$ & $v_{3}$ & $v_{2}$ & $v_{4}$ & $v_{1}$ & --- \\
\hline $\mathrm{HfSiO}_{4}{ }^{81}$ & 448 & --- & 984 & 1018 & --- & --- & --- \\
$\mathrm{HfSiO}_{4}{ }^{14}$ & 450.3 & 639.5 & 985.7 & 1021.5 & --- & --- & --- & --- \\
$\mathrm{HfSiO}_{4}{ }^{31}$ & --- & --- & --- & -- & 430 & 610 & 890 & 1020 \\
$\mathrm{HfSiO}_{4}{ }^{13}$ & --- & --- & --- & --- & 440 & 615 & 915 & 1020 \\
$\mathrm{HfSiO}_{4}$ (this study) & 451 & --- & 979 & 1015 & 433 & 627 & 868 \\
\hline
\end{tabular}




\section{Effect of the starting hafnium and silicate concentrations}

Since the concentration of the reactants were crucial parameter for the synthesis of $\mathrm{ThSiO}_{4}$ and $\mathrm{CeSiO}_{4},{ }^{49,64,65}$ it was suspected that the concentration of the hafnium and silicate present in the starting mixture could affect the saturation indexes in solution, and thus the formation of $\mathrm{HfSiO}_{4}$. In this frame, several syntheses were performed under hydrothermal conditions with different concentrations. The impact of the concentrations of both reactants was followed between $8.4 \times 10^{-3} \mathrm{~mol} \cdot \mathrm{L}^{-1}$ and $1.0 \mathrm{~mol} \cdot \mathrm{L}^{-1}$, keeping constant the $\mathrm{Si}: \mathrm{Hf}$ molar ratio $(1.03)$, the initial $\mathrm{pH}$ value $(\mathrm{pH}=0.5)$ and the conditions of the hydrothermal treatment $\left(\mathrm{T}=250^{\circ} \mathrm{C}, \mathrm{t}=\right.$ 24 hours). As a result, pure $\mathrm{HfSiO}_{4}$ was obtained for $\mathrm{C}_{\mathrm{Hf}}$ $\geq 0.21 \mathrm{~mol} \cdot \mathrm{L}^{-1}$ whereas the formation of $\mathrm{HfO}_{2}$ was observed as a by-product for lower concentrations (Figure 3). In the less concentrated media, the silicate concentrations in solution were not sufficient to fully counterbalance the hydrolysis of hafnium. Therefore, the formation of hafnium silicate was favored for $\mathrm{C}_{\mathrm{Hf}} \geq 0.21 \mathrm{~mol} \cdot \mathrm{L}^{-1}$.

Moreover, the considered concentration significantly affected the crystallization state of $\mathrm{HfSiO}_{4}$. Specifically, decreasing the hafnium and silicate ions concentration in the reactive media induced the increase of the crystallite size of $\mathrm{HfSiO}_{4}$ (Figure 4 and Table 1). This behavior is similar to what was observed previously for $\mathrm{ThSiO}_{4}{ }^{64}$ It may be attributed to the faster kinetics of nucleation in the more concentrated reactive media, leading to the formation of numerous nucleation centers, whose growth may be hindered by the limited amounts of reactants in the synthesis medium. Additionally, the Rietveld refinements allowed to observe the increase of the $\mathrm{HfSiO}_{4}$ 's lattice parameters and volume cell and the decrease of the crystallite size (Table 1 and Figure S3). Furthermore, the decrease of the crystallite size could be observed in each crystalline planes (Table S2), especially the low size value obtained in the (hkl) planes with $1 \neq 0$ at high concentration could explain the anisotropic effect which could be observed with the widening of the corresponding peaks.

\section{Impact of the hydrothermal treatment (temperature and duration)}

In order to identify the impact of the temperature of the hydrothermal treatment on the formation of $\mathrm{HfSiO}_{4}$, several experiments were performed at $150^{\circ} \mathrm{C}, 200^{\circ} \mathrm{C}$ and $250^{\circ} \mathrm{C}$, keeping constant the concentration of the starting hafnium $\left(0.21 \mathrm{~mol} \cdot \mathrm{L}^{-1}\right)$, the molar Si:Hf ratio (1.03), the starting $\mathrm{pH}$ value $(\mathrm{pH}=0.5)$ and the heating time $(\mathrm{t}=24$ hours $)$. From PXRD analyses, $\mathrm{HfSiO}_{4}$ was formed whatever the temperature of synthesis (Figure 5), which was also confirmed by IR spectroscopy (Figure S3). Additional experiments performed in the same conditions at $100^{\circ} \mathrm{C}$ did not lead to the formation of $\mathrm{HfSiO}_{4}$ after 24 hours holding time.

However, working at the lower temperatures led to the formation of $\mathrm{HfSiO}_{4}$ compounds exhibiting a very strong anisotropic effect (Figure 5). Indeed, the ( $h k l)$ reflections involving the $c$ axis were strongly broadened and attenuated whereas the ( $h k 0)$ reflections were finer and more intense when the temperature of the hydrothermal treatment decreased, which underlined the formation of platelet crystallites. Considering that the decreasing temperature was associated to slower kinetics of reaction, this phenomenon was assigned to the growth process of $\mathrm{HfSiO}_{4}$ crystallites, involving first the formation of bidimensional crystallites and then crystal growth to form three-dimensional particles. Finally, varying the starting $\mathrm{pH}$ value at $150^{\circ} \mathrm{C}$ or $200^{\circ} \mathrm{C}$ confirmed that $\mathrm{HfSiO}_{4}$ was always obtained for $\mathrm{pH}<1.6$ (Figure $\mathbf{S 4}$ and Figure S5), as already discussed for the experiments at $250^{\circ} \mathrm{C}$.

Moreover, the preferential growth observed in this study is in agreement with the results reported recently by Calas et al. for the alteration of $\mathrm{Hf}$-bearing borosilicate glasses at $90^{\circ} \mathrm{C}$ and $\mathrm{pH}=1$ in aqueous solution, showing the (200) reflection of hafnon as the only observable diffraction peak in their conditions. ${ }^{77}$ The reflections (220), (400) and (420) are invisible due to their low intensity compared to the (200), while the $(h k l)$ peaks with $1 \neq 0$ are invisible due to an anisotropic effect.

Increasing the temperature of the hydrothermal treatment led to the decrease of the unit-cell parameters of $\mathrm{HfSiO}_{4}$ (Figure S8 and Table 1). No significant variation of the average crystallite size was observed (Figure S8). However, Rietveld refinements performed on the PXRD patterns allowed to confirm the qualitative results suspected on the anisotropy which could be explained by the crystallite growth along the (hkl) planes with $1 \neq 0$ (Figure 6 and Table S2) when the temperature of the hydrothermal treatment increased.

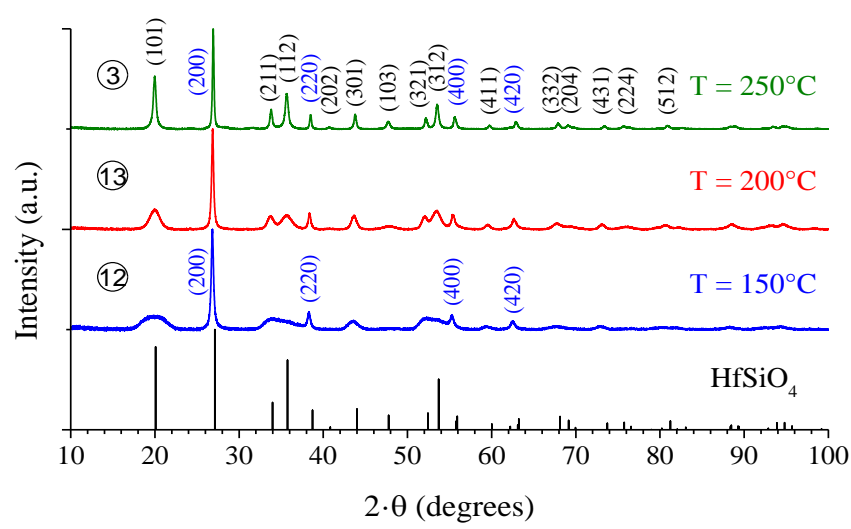

Figure 5. PXRD pattern and corresponding Miller index obtained for samples prepared under hydrothermal conditions with starting silicon and hafnium concentrations of $0.21 \mathrm{~mol} \cdot \mathrm{L}^{-1}$ and $\mathrm{pH}=0.5$, after hydrothermal treatment performed for 24 hours at $\mathrm{T}=150^{\circ} \mathrm{C}$ (12), at $\mathrm{T}=200^{\circ} \mathrm{C}$ (13) and at $\mathrm{T}=250^{\circ} \mathrm{C}$ (3). The characteristic XRD lines of $\mathrm{HfSiO}_{4}$ were extracted from ${ }^{28}$.

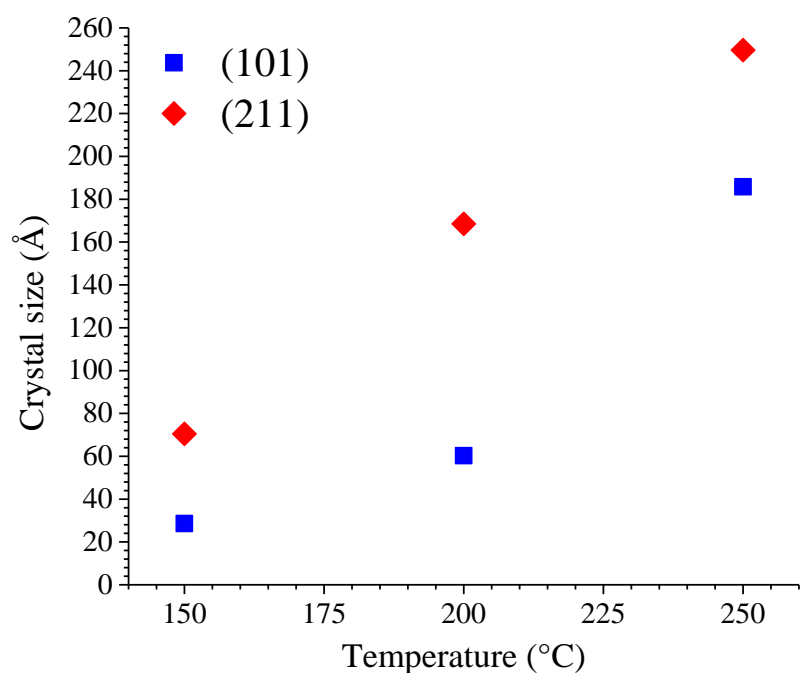

Figure 6. Crystallite size of $\mathrm{HfSiO}_{4}$ along (101) and (211) crystalline planes determined by Rietveld refinement as a function of the temperature of the hydrothermal treatment for samples prepared 
under hydrothermal conditions $(\mathrm{t}=24$ hours, $\mathrm{pH}=0.5$ and $\left.\mathrm{C}_{\mathrm{Hf}}=0.21 \mathrm{~mol} \cdot \mathrm{L}^{-1}\right)$.

Thermogravimetric analyses, coupled with mass spectroscopy, performed between room temperature and $1000^{\circ} \mathrm{C}$ under air atmosphere, with the samples dried overnight at $60^{\circ} \mathrm{C}$, allowed to observe the loss of water in two steps. The first one around $100^{\circ} \mathrm{C}$ corresponded to the elimination of free water and the second one between $200^{\circ} \mathrm{C}$ and $850^{\circ} \mathrm{C}$ was probably associated to the elimination of water inserted in $\mathrm{HfSiO}_{4}$ structure (as $\mathrm{H}_{2} \mathrm{O}$ or $\mathrm{HO}^{-}$group).

The characterizations performed on the TGA analyses residues allowed to confirm that the final phase obtained corresponded to $\mathrm{HfSiO}_{4}$ as single crystalline phase, whatever the temperature of hydrothermal treatment considered. It worth noting that the $\mathrm{HfSiO}_{4}$ lattice parameters evolved during the thermogravimetric analysis to reach parameters close to reference values: $a=6.5714(8) \AA, \quad c=5.9685(11) \AA \quad$ and $\mathrm{V}=257.74(7) \AA^{3}$ (against $a=6.5725(7) \AA, c=5.9632(4) \AA$ i.e. $V=257.60(7) \AA^{328}$ ) (Table 1). Raman and infrared spectroscopy characterizations did not lead to significant differences compared to the spectra measured before the thermogravimetric analyses.

In order to evidence the impact of the duration of the hydrothermal treatment on the formation of $\mathrm{HfSiO}_{4}$, several experiments were also performed at $250^{\circ} \mathrm{C}$, for $\mathrm{pH}=0.5$ and $\mathrm{C}_{\mathrm{Hf}}=0.21 \mathrm{~mol} \cdot \mathrm{L}^{-1}$ with holding times spread from 1 day to 20 days. From PXRD analysis, it was clear that $\mathrm{HfSiO}_{4}$ was always single phase and was not degraded by extending the holding time (Figure 7).

Moreover, extending the duration of the hydrothermal treatment did not lead to significant change of the $\mathrm{HfSiO}_{4}$ unit cell parameters determined by Rietveld refinement (Table 1). The $\mathrm{HfSiO}_{4}$ lattice parameters reached $a=6.5937(1) \AA$, $c=5.9605(1) \AA$ and $\mathrm{V}=259.14(1) \AA^{3}$ for 20 days of hydrothermal treatment (Figure 8). As already described, the lattice parameters obtained were slightly different to those obtained by high temperature methods $(a=6.5725(7) \AA$, $c=5.9632(4) \AA$ and $\mathrm{V}=257.60(7) \AA^{328}$ ), which might correspond to the insertion of hydroxide groups in the $\mathrm{HfSiO}_{4}$ structure. $^{64,79}$ The extension of the heating time tended to reduce the anisotropic effect evidenced by PXRD. Therefore, initial $\mathrm{HfSiO}_{4}$ platelets crystallites may evolve to form 3D particles through crystal growth process.

The determination of the size of the $\mathrm{HfSiO}_{4}$ crystallites performed by Rietveld refinement indicated that increasing the duration of the hydrothermal treatment promoted their growth (Figure 9).

The direct comparison by SEM of the samples prepared at $250^{\circ} \mathrm{C}$ clearly confirmed the growth of $\mathrm{HfSiO}_{4}$ grains from $60 \mathrm{~nm}$ after 1 day to $\sim 200 \mathrm{~nm}$ after 7 days and $\sim 450 \mathrm{~nm}$ after 20 days (Figure 10). It also exhibited the evolution of the grain morphology with the clear identification of a square based bipyramid morphology characteristic of zircon-type materials, for the hydrothermal treatments extended for 7 days and more. ${ }^{82}$ This evolution of morphology may be correlated to the crystalline growth of the $\mathrm{HfSiO}_{4}$ grains. Moreover, $\mathrm{HfSiO}_{4}$ particles also appeared to be very flattened and may be correlated to the anisotropic effect previously observed. However, it is worth noting that a size discrepancy was observed between the crystallite size determined by XRD method (Figure 9) and grain size measured thanks to SEM. Therefore, it can be concluded that these grains observed are polycrystalline, This behavior was already observed for other silicate based compounds including $\mathrm{ThSiO}_{4} \cdot{ }^{64}$ Additionally, SEMEDX characterization allowed to confirm the sample composition, without any metallic insertion in $\mathrm{HfSiO}_{4}$ (Figure S13).

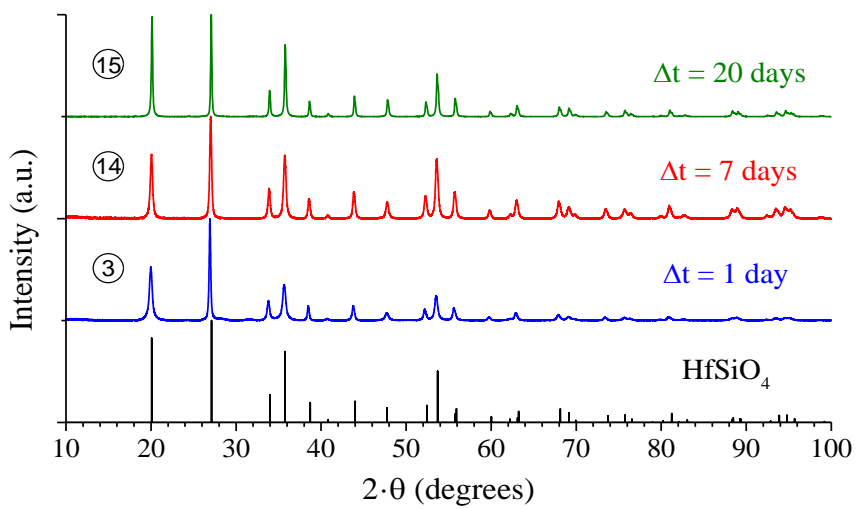

Figure 7. PXRD patterns recorded for samples prepared under hydrothermal conditions $\left(\mathrm{T}=250^{\circ} \mathrm{C}\right)$ starting with $\mathrm{pH}=0.5$ and $\mathrm{C}_{\mathrm{Hf}}=0.21 \mathrm{~mol} \cdot \mathrm{L}^{-1}$ and for various heating times: 1 day (3), 7 days (14) and 20 days (15). The XRD lines characteristic of $\mathrm{HfSiO}_{4}$ were extracted from ${ }^{28}$.

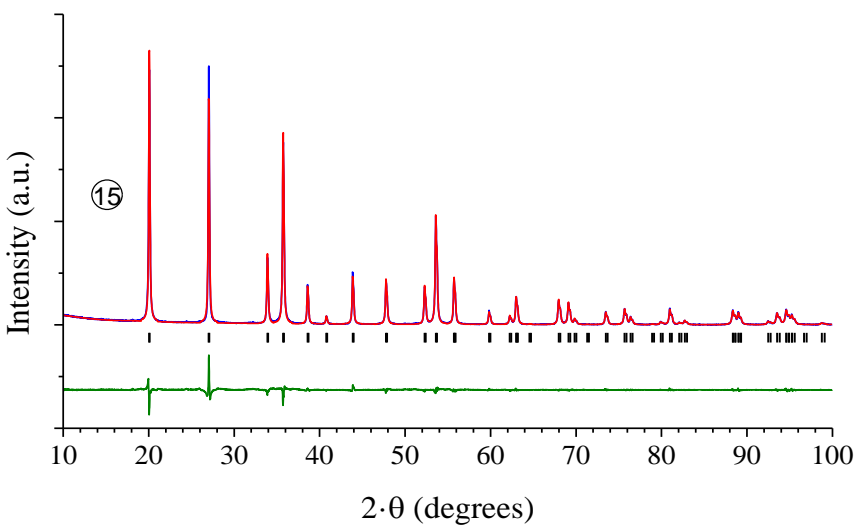

Figure 8. $\mathrm{PXRD}$ diagram of $\mathrm{HfSiO}_{4}$ prepared under hydrothermal conditions $\left(\mathrm{T}=250^{\circ} \mathrm{C}, \mathrm{t}=20\right.$ days $)$ starting with $\mathrm{pH}=0.5$ and $\mathrm{C}_{\mathrm{Hf}}=0.21 \mathrm{~mol} \cdot \mathrm{L}^{-1}$, and associated calculated and difference profile obtained by Rietveld refinement.

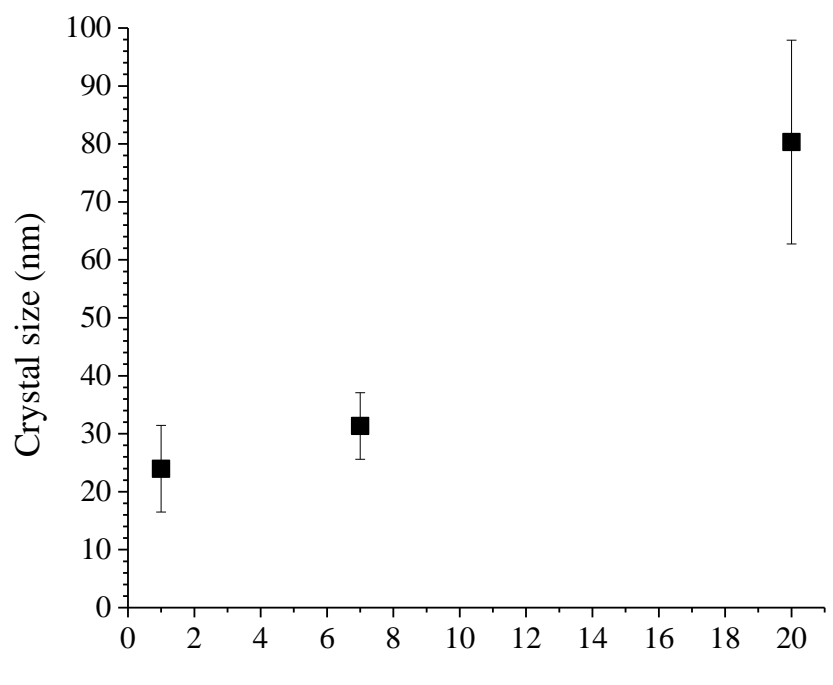

Hydrothermal treatment duration (days)

Figure 9. $\mathrm{HfSiO}_{4}$ crystallite size determined by Rietveld refinement as a function of the duration of the hydrothermal treatment for samples prepared under hydrothermal conditions $\left(\mathrm{T}=250^{\circ} \mathrm{C}, \mathrm{pH}=0.5\right.$ and $\left.\mathrm{C}_{\mathrm{Hf}}=0.21 \mathrm{~mol} \cdot \mathrm{L}^{-1}\right)$. 


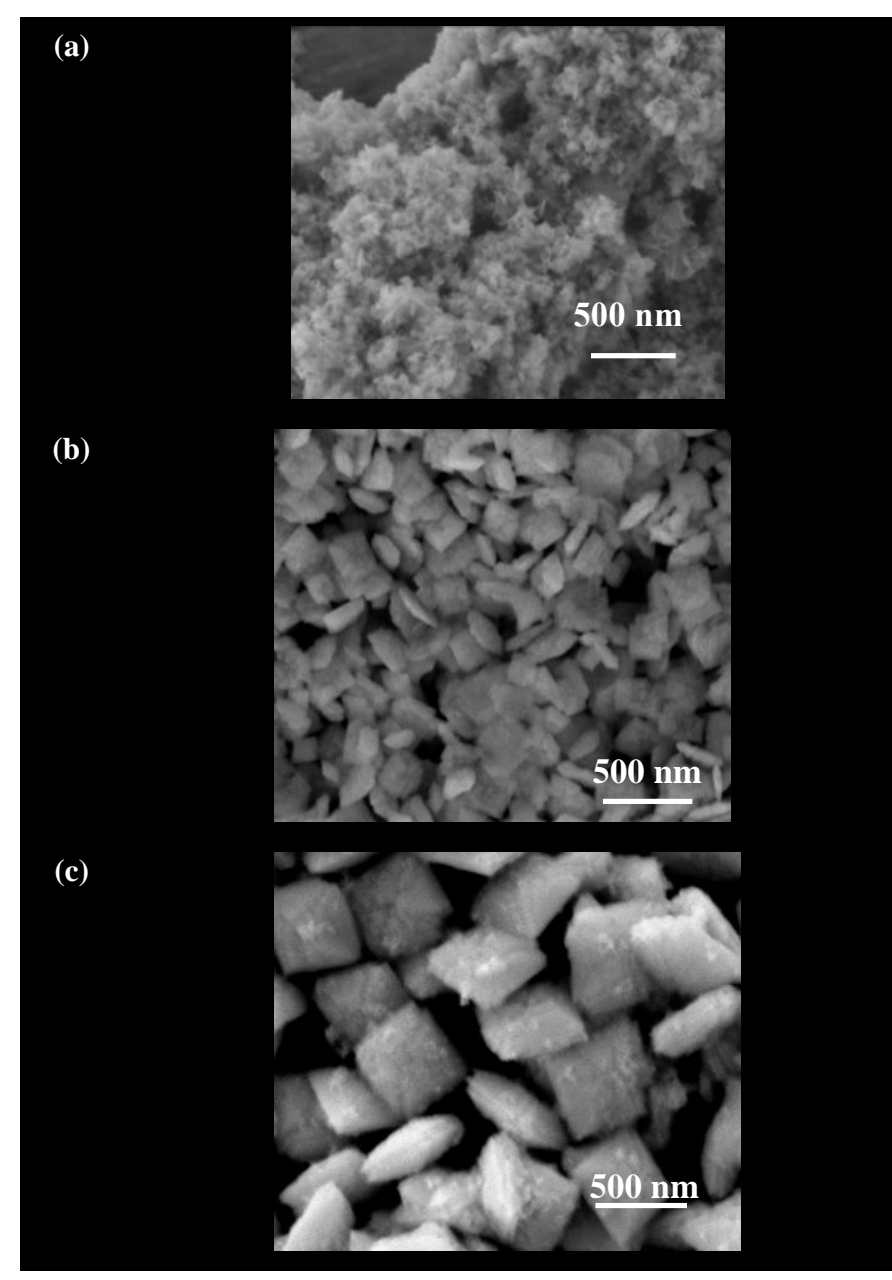

Figure 10. SEM micrographs recorded for $\mathrm{HfSiO}_{4}$ samples prepared under hydrothermal conditions at $\mathrm{T}=250^{\circ} \mathrm{C}$, starting with $\mathrm{pH}=0.5$ and $\mathrm{C}_{\mathrm{Hf}}=0.21 \mathrm{~mol} \cdot \mathrm{L}^{-1}$, and for heating times of 1 day (3) (a), 7 days (14) (b) and 20 days (15) (c).

\section{CONCLUSION}

The multiparametric study of $\mathrm{HfSiO}_{4}$ synthesis allowed determining an appropriate set of hydrothermal conditions to prepare single phase samples, which are listed below:

- acidic reactive media (typically with $\mathrm{pH} \leq 1.6$, fixed to $\mathrm{pH}=0.5$ in this study);

- hafnium and silicate concentrations over $0.21 \mathrm{~mol} \cdot \mathrm{L}^{-1}$ with a molar $\mathrm{Si} / \mathrm{Hf}$ ratio of 1.03 in order to avoid the formation of hafnium dioxide in the final mixtures;

- hydrothermal treatment for 24 hours at $\mathrm{T} \geq 150^{\circ} \mathrm{C}$. Increasing the temperature and the duration of the hydrothermal treatment promoted the formation and then the growth of the square based bipyramid feature.

The formation of $\mathrm{HfO}_{2}$ in the place of $\mathrm{HfSiO}_{4}$ at high $\mathrm{pH}$ and low reactant concentration was easily explained by the competition between the formation of hafnium hydroxide and hafnium silicate. This behavior and more generally the conditions associated to the synthesis of $\mathrm{HfSiO}_{4}$ are very similar to those of thorite $\left(\mathrm{ThSiO}_{4}\right)$ in ligand free reactive media.

Moreover, it worth noting that such kind of synthesis of $\mathrm{HfSiO}_{4}$ in soft hydrothermal conditions or hydrothermally assisted synthesis could be considered as a potential option to increase the solubility of tetravalent actinides in zircon-type materials or to prepare hafnon based materials doped by divalent or trivalent elements.

\section{ASSOCIATED CONTENT}

\section{Supporting Information}

The Supporting Information is available free of charge on the ACS Publications website.

Table S1 reporting the parameters considered for all the syntheses of $\mathrm{HfSiO}_{4}$ under hydrothermal conditions. Table $\mathbf{S 2}$ gathering the crystallite size along different (hkl) plan determined by Rietveld refinement for $\mathrm{HfSiO}_{4}$ samples. Table $\mathbf{S 3}$ reporting the assignment of the bands associated to silicate groups in zircon type silicates.

Figure S1 representing the variation of the $\mathrm{HfSiO}_{4}$ unit cell parameters and volume and of the crystallite size as a function of the starting $\mathrm{pH}$. Figure $\mathbf{S 2}$ representing the IR spectra obtained for $\mathrm{HfSiO}_{4}$ samples prepared considering various initial $\mathrm{pH}$ values. Figure S3 representing the variation of the $\mathrm{HfSiO}_{4}$ unit cell parameters and volume as a function of the reactant concentration. Figure S4 representing the IR spectra obtained for $\mathrm{HfSiO}_{4}$ samples prepared with various hafnium and silicon concentrations. Figure S5 representing the IR spectra obtained for $\mathrm{HfSiO}_{4}$ samples prepared at various temperatures of hydrothermal treatment. Figure S6 and Figure S7 representing the PXRD patterns obtained for $\mathrm{HfSiO}_{4}$ samples prepared at $150^{\circ} \mathrm{C}$ and at $200^{\circ} \mathrm{C}$, respectively, with various starting $\mathrm{pH}$ values. Figure S8 representing the variation of the $\mathrm{HfSiO}_{4}$ unit cell parameters and volume and of the crystallite size versus the temperature of the hydrothermal treatment. Figure $\mathbf{S 9}$ representing the thermogravimetric analyses for $\mathrm{HfSiO}_{4}$ samples prepared at $150^{\circ} \mathrm{C}$ and $250^{\circ} \mathrm{C}$. Figure S10 representing the IR spectra obtained for $\mathrm{HfSiO}_{4}$ samples prepared for various heating times at $250^{\circ} \mathrm{C}$. Figure $\mathbf{S 1 1}$ representing the variation of the $\mathrm{HfSiO}_{4}$ unit-cell parameters and volume and of the crystallite size versus the heating time of the hydrothermal treatment. Figure S12 representing the SEM micrographs recorded for $\mathrm{HfSiO}_{4}$ samples prepared at $150^{\circ} \mathrm{C}$ and $250^{\circ} \mathrm{C}$. Figure $\mathrm{S13}$ representing the EDX analysis of $\mathrm{HfSiO}_{4}$.

\section{AUTHOR INFORMATION}

\section{Corresponding Author}

* Prof. Nicolas Dacheux

ICSM, CEA, CNRS, ENSCM, Univ Montpellier

Site de Marcoule, Bât. 426

BP 17171, 30207 Bagnols-sur-Cèze

France

Phone : +33466339205

Fax : +33 466797611

e-mail : nicolas.dacheux@umontpellier.fr

\section{Present Addresses}

$\S$ The European Synchrotron, CS40220, 38043 Grenoble Cedex 9, France.

" Helmholtz Zentrum Dresden-Rossendorf (HZDR), Institute of Resource Ecology, P.O. Box 510119, 01314, Dresden, Germany.

\section{Author Contributions}

The manuscript was written through contributions of all authors.

\section{Notes}

The authors declare no competing financial interest.

\section{ACKNOWLEDGMENT}

The authors would like to thank R. Podor, J. Lautru and V. Trillaud (from ICSM) for supporting SEM experiments. 


\section{REFERENCES}

(1) Curtis, C. E.; Doney, L. M.; Johnson, J. R., Some Properties of Hafnium Oxide, Hafnium Silicate, Calcium Hafnate, and Hafnium Carbide. J. Am. Ceram. Soc. 1954, 37, 458-465.

(2) Keller, C., Untersuchungen über die Germanate und Silikate des Typs $\mathrm{ABO}_{4}$ der vierwertigen Elemente Thorium bis Americium. Nukleonik 1963, 5, 41-48.

(3) Speer, J. A., The actinide orthosilicates. Rev. Mineral. Geochem. 1980, 5, 113-135.

(4) Skakle, J. M. S.; Dickson, C. L.; Glasser, F. P., The crystal structures of $\mathrm{CeSiO}_{4}$ and $\mathrm{Ca}_{2} \mathrm{Ce}_{8}\left(\mathrm{SiO}_{4}\right)_{6} \mathrm{O}_{2}$. Powder Diffr. 2000, 15, 234-238.

(5) Ramakrishnan, S. S.; Gokhale, K. V. G. K.; Subbarao, E. C., Solid solubility in the system zircon-hafnon. Mater. Res. Bull. 1969, 4, 323-327.

(6) Hoskin, P. W. O.; Rodgers, K. A., Raman spectral shift in the isomorphous series $\left(\mathrm{Zr}_{1-\mathrm{x}} \mathrm{Hf}_{\mathrm{x}}\right) \mathrm{SiO}_{4}$. Eur. J. Solid State Inorg. Chem. 1996, 33, 1111-1121.

(7) Cota, A.; Burton, B. P.; Chain, P.; Pavon, E.; Alba, M. D., Solution properties of the system $\mathrm{ZrSiO}_{4}-\mathrm{HfSiO}_{4}$ : a computational and experimental study. J. Phys. Chem. C 2013, 117, 10013-10019.

(8) Hoskin, P. W. O.; Schaltegger, U., The composition of zircon and igneous and metamorphic petrogenesis. Rev. Mineral. Geochem. 2003, 53, 27-62.

(9) Ballard, J. R.; Palin, J. M.; Campbell, I. H., Relative oxidation states of magmas inferred from $\mathrm{Ce}(\mathrm{IV}) / \mathrm{Ce}(\mathrm{III})$ in zircon: Application to porphyrycopper deposits of northern Chile. Contrib. Mineral. Petrol. 2002, 144, 347-364.

(10) Uher, P.; Cerny, P., Zircon in hercynian granitic pegmatites of the Western Carpathians, Slovakia. Geol. Carpathica 1998, 49, 261270.

(11) Correia Neves, J. M.; Lopes Nunes, J. E.; Sahama, T. G., High hafnium members of the zircon-hafnon series from the granite pegmatites of Zambézia, Mozambique. Contrib. Mineral. Petrol. 1974, 48, 73-80.

(12) Kanno, Y., Effect of dopants on the formation of hafnon via a sol-gel route. J. Mater. Sci. Lett. 1993, 12, 1807-1809.

(13) Varghese, J.; Joseph, T.; Surendran, K. P.; Rajan, T. P. D.; Sebastian, M. T., Hafnium silicate: a new microwave dielectric ceramic with low thermal expansivity. Dalton Trans. 2015, 44, 51465152.

(14) Manoun, B.; Downs, R. T.; Saxena, S. K., A high-pressure Raman spectroscopic study of hafnon, HfSiO4. Am. Mineral. 2006, 91, 1888-1892.

(15) Lutze, W.; Ewing, R. C., Radioactive waste forms for the future; New York: North-Holland; NY 1988.

(16) Meldrum, A.; Zinkle, S. J.; Boatner, L. A.; Ewing, R. C., A transient liquid-like phase in the displacement cascades of zircon, hafnon and thorite. Nature 1998, 395, 56-58.

(17) Meldrum, A.; Zinkle, S. J.; Boatner, L. A.; Wu, M.; Mu, R.; Ueda, A.; Henderson, D. O.; Ewing, R. C., Radiation effects in zircon, hafnon and thorite implications for $\mathrm{Pu}$ disposals. Mater. Res. Soc. Symp. Proc. 1998, 540.

(18) Lutze, W.; Ewing, R. C.; Helean, K. B.; Gong, W. L., Zircon: a host phase for the disposal of weapons plutonium. University of New Mexico report 1999.

(19) Ewing, R. C.; Meldrum, A.; Wang, L. M.; Weber, W. J.; Corrales, L. R., Radiation effects in zircon. Rev. Mineral. Geochem. 2003, 388-425.

(20) Burakov, B. E.; Anderson, E. B.; Zamoryanskaya, M. V.; Yagovkina, M. A.; Strykanova, E. E., Synthesis and study of ${ }^{239} \mathrm{Pu}-$ doped ceramics based on zircon $(\mathrm{Zr}, \mathrm{Pu}) \mathrm{SiO}_{4}$, and hafnon (Hf,Pu)SiO 4 . Mater. Res. Soc. Symp. Proc. 2001, 663, 307-313.

(21) Salt, D. J.; Hornung, G., Synthesis and X-ray study of hafnium silicate. J. Am. Ceram. Soc. 1967, 50, 549-550.

(22) Vasquez, A.; Rodgers, J. D.; Maciel, A.; Fraga, E. R., Nuclear quadrupole interaction in hafnon. Rev. Bras. Fis. 1973, 3, 311-315.

(23) Ueno, S.; Jayaseelan, D. D.; Ohji, T.; Lin, H. T., Corrosion and oxidation behavior of $\mathrm{ASiO} 4(\mathrm{~A}=\mathrm{Ti}, \mathrm{Zr}$ and $\mathrm{Hf})$ and silicon nitride with an $\mathrm{HfSiO} 4$ environmental barrier coating. J. Ceram. Process. Res. 2005, 6, 81-84.

(24) O'Neill, H. S. C., Free energy of formation of zircon and hafnon. Am. Mineral. 2006, 91, 1134-1141.

(25) Chain, C. Y.; Damonte, L. C.; Ferrari, S.; Munoz, E.; Rodriguez Torres, C.; Pasquevich, A. F., PAC study in the HfO2$\mathrm{SiO} 2$ system. J. Alloys Compd. 2010, 495, 527-531.

(26) Kanno, Y., Thermodynamics and crystallographic discussion of the formation and dissociation of zircon. J. Mater. Sci. 1989, 24, 2415-2420.

(27) Jaeger, H.; McBride, S. P., Perturbed angular correlation measurement of the electric field gradient at $181 \mathrm{Ta}$ in $\mathrm{ZrSiO} 4$ and HfSiO4. Hyperfine Interact. 2007, 177, 51-56.

(28) Speer, J. A.; Cooper, B. J., Crystal structure of synthetic hafnon, $\mathrm{HfSiO}_{4}$, comparison with zircon and the actinide orthosilicates. Am. Mineral. 1982, 67, 804-808.

(29) Fuhrmann, J.; Pickardt, J., Bildung von $\mathrm{HfSiO}_{4}$-einkristallen durch chemische Transportreaktion. Z. Anorg. Allg. Chem. 1986, 532, 171-174.

(30) Punchaipetch, P.; Pant, G.; Quevedo-Lopez, M.; Zhang, H.; ElBouanani, M.; Kim, M. J.; Wallace, R. M.; Gnade, B. E., Hafnium silicate formation by ultra-violet/ozone oxidation of hafnium silicide. Thin Solid Films 2003, 425, 68-71.

(31) Caruba, R.; Baumer, A.; Turco, G., Nouvelles synthèses hydrothermales du zircon : substitutions isomorphiques; relation morphologie-milieu de croissance. Geochim. Cosmochim. Acta 1975, 39, 11-26.

(32) McNeil, A. G.; Linnen, R. L.; Flemming, R. L., Hydrothermal synthesis of columbite-(Mn), Tantalite-(Mn), hafnon and zircon at $800-850^{\circ} \mathrm{C}$ and $200 \mathrm{MPa}$. Can. Mineral. 2015, 53, 1073-1081.

(33) Mumpton, F. A.; Roy, R., Hydrothermal stability studies of the zircon-thorite group. Geochim. Cosmochim. Acta 1961, 21, 217-238.

(34) Frondel, C.; Collette, R. L., Hydrothermal synthesis of zircon, thorite and huttonite. The Am. Mineral. 1957, 42, 759-765.

(35) Valero, R. Mécanismes de la synthèse hydrothermale du zircon. Ph.D. Thesis. Université de Haute Alsace, Mulhouse, France, 1997.

(36) Valero, R.; Delmotte, L.; Paillaud, J. L.; Durand, B.; Guth, J. L.; Chopin, T., A new hydrothermal fluoro-zircon. J. Mater. Chem. 1999, 9, 117-123.

(37) Valero, R.; Durand, B.; Guth, J. L.; Chopin, T., Mechanism of hydrothermal synthesis of zircon in a fluoride medium. J. Sol-Gel Sci. Technol. 1998, 13, 119-124.

(38) Valero, R.; Durand, B.; Guth, J. L.; Chopin, T., Hydrothermal synthesis of porous zircon in basic fluorinated medium. Microporous Mesoporous Mater. 1999, 29, 311-318.

(39) Valero, R.; Durand, B.; Guth, J. L.; Chopin, T., Influence des ions fluorures et de la silice amorphe sur la solubilité des gels de zircone et caracteriation des fluroro-complexes de zirconium en milieu moyennement acide. Can. J. Chem. 1999, 77, 2099-2104.

(40) Valero, R.; Paillaud, J. L.; Durand, B.; Guth, J. L.; Chopin, T., Rietveld refinement of two fluoro-hydroxy-zircons. Eur. J. Solid State Inorg. Chem. 1998, 35, 735-743.

(41) Kido, H.; Komarneni, S., Hydrothermal processing of zircon. Trans. Mater. Res. Soc. Jpn. 1990, 358-369.

(42) Mosset, A.; Baules, P.; Lecante, P.; Trombe, J. C.; Ahamdane, H.; Bensamka, F., A new solution route to silicates Part 4. Submicronic zircon powders. J. Mater. Chem. 1996, 6, 1527-1532.

(43) Caruba, R.; Baumer, A.; Ganteaume, M.; Iacconi, P., An experimental study of hydroxyl groups and water in synthetic and natural zircons: a model of the metamict state. Am. Mineral. 1985, 70, 1224-1231.

(44) Ilyushin, G. D., Phase relations in the $\mathrm{Na}_{2} \mathrm{CO}_{3}-\mathrm{ZrO}_{2}-\mathrm{SiO}_{2}-\mathrm{H}_{2} \mathrm{O}$ system at 0.1 and $0.05 \mathrm{GPa}$ and $450^{\circ} \mathrm{C}$. Inorg. Mater. 2002, 38, 12491257.

(45) Ilyushin, G. D.; Dem'yanets, L. N., KOH- $\mathrm{ZrO}_{2}-\mathrm{SiO}_{2}-\mathrm{H}_{2} \mathrm{O}$ hydrothermal system: formation of potassium zirconosilicates and crystallochemical correlations among them. Growth Cryst. 1996, 20, 89-99.

(46) Ilyushin, G. D.; Dem'yanets, L. N., Hydrothermal synthesis of $\mathrm{K}_{2} \mathrm{ZrSi}_{6} \mathrm{O}_{15}, \mathrm{~K}_{2} \mathrm{ZrSi}_{3} \mathrm{O}_{9}, \mathrm{~K}_{2} \mathrm{ZrSi}_{2} \mathrm{O}_{7}$, and $\mathrm{ZrSiO}_{4}$ in the system $\mathrm{KOH}-$ $\mathrm{ZrO}_{2}-\mathrm{SiO}_{2}-\mathrm{H}_{2} \mathrm{O}$. Inorg. Mater. 2002, 38, 612-616. 
(47) Dickson, C. L.; Glasser, F. P., Cerium(III, IV) in cement Implications for actinide (III, IV) immobilisation. Cem. Concr. Res. 2000, 30, 1619-1623.

(48) Estevenon, P.; Kaczmarek, T.; Vadot, F.; Dumas, T.; Solari, P. L.; Welcomme, E.; Szenknect, S.; Mesbah, A.; Moisy, P.; Poinssot, C.; Dacheux, N., Formation of $\mathrm{CeSiO}_{4}$ from cerium (III) silicate precursors. Dalton Trans. 2019, 48, 10455-10463.

(49) Estevenon, P.; Welcomme, E.; Szenknect, S.; Mesbah, A.; Moisy, P.; Poinssot, C.; Dacheux, N., Preparation of $\mathrm{CeSiO}_{4}$ from aqueous precursors under soft hydrothermal conditions. Dalton Trans. 2019, 48, 7551-7559.

(50) Fuchs, L. H.; Gebert, E., X-ray studies of synthetic coffinite, thorite and uranothorites. The Am. Mineral. 1958, 43, 243-248.

(51) Sinha, D. P.; Prasad, R., On the synthetic preparation and lattice structure of thorite. J. Inorg. Nucl. Chem. 1973, 35, 2612-2614.

(52) Clavier, N.; Szenknect, S.; Costin, D. T.; Mesbah, A.; Poinssot, C.; Dacheux, N., From thorite to coffinite: A spectroscopic study of $\mathrm{Th}_{1-\mathrm{x}} \mathrm{U}_{\mathrm{x}} \mathrm{SiO}_{4}$ solid solutions. Spectrochim. Acta, Part A 118 2014, 118 , 302-307.

(53) Clavier, N.; Szenknect, S.; Costin, D. T.; Mesbah, A.; Ravaux, J.; Poinssot, C.; Dacheux, N., Purification of uranothorite solid solutions from polyphase systems. J. Nucl. Mater. 2013, 441, 73-83.

(54) Costin, D. T. Solutions solides d'uranothorite : de la préparation à la dissolution. Ph.D. Thesis. Université de Montpellier 2, Montpellier, France, 2012.

(55) Costin, D. T.; Mesbah, A.; Clavier, N.; Dacheux, N.; Poinssot, C.; Szenknect, S.; Ravaux, J., How to explain the difficulties in the coffinite synthesis from the study of uranothorite? Inorg. Chem. 2011, 50, 11117-11126.

(56) Costin, D. T.; Mesbah, A.; Clavier, N.; Szenknect, S.; Dacheux, N.; Poinssot, C.; Ravaux, J.; Brau, H. P., Preparation and characterization of synthetic $\mathrm{Th}_{0.5} \mathrm{U}_{0.5} \mathrm{SiO}_{4}$ uranothorite. Prog. Nucl. Energy 2012, 57, 155-160.

(57) Szenknect, S.; Costin, D. T.; Clavier, N.; Mesbah, A.; Poinssot, C.; Vitorge, P.; Dacheux, N., From uranothorites to coffinite: a solid solution route to the thermodynamic properties of $\mathrm{USiO}_{4}$. Inorg. Chem. 2013, 52, 6957-6968.

(58) Bauer, J. D.; Labs, S.; Bayarjargal, L.; Morgenroth, W.; Weiss, S.; Curtius, H.; Bosbach, D.; Winkler, B., The crystal structures of synthetic coffinite, $\mathrm{USiO}_{4}$, and uranothorite, $\mathrm{U}_{\mathrm{x}} \mathrm{Th}_{1-\mathrm{x}} \mathrm{SiO}_{4}$, analyzed by Powder Diffr.. DESY annual report 2013

(59) Labs, S., Secondary uranium phases of spent nuclear fuel coffinite, $\mathrm{USiO}_{4}$, and studtite, $\mathrm{UO}_{4} \cdot 4 \mathrm{H}_{2} \mathrm{O}$ - Synthesis, characterization, and investigations regarding phase stability. Schriften des Forschungszentrums Jülich 2015, 267.

(60) Labs, S.; Hennig, C.; Weiss, S.; Curtius, H.; Zänker, H.; Bosbach, D., Synthesis of coffinite, $\mathrm{USiO}_{4}$, and structural investigations of $\mathrm{U}_{\mathrm{x}} \mathrm{Th}_{(1-\mathrm{x})} \mathrm{SiO}_{4}$ solid solutions. Environ. Sci. Technol. 2014, 48, 854-860.

(61) Guo, X.; Mesbah, A.; Clavier, N.; Poinssot, C.; Wu, D.; Xu, H.; Dacheux, N.; Ewing, R. C.; Navrotsky, A., Energetics of a uranothorite $\left(\mathrm{Th}_{1-\mathrm{x}} \mathrm{UxSiO}_{4}\right)$ solid solution. Chem. Mater. 2016, 28, 7117-7124.

(62) Mesbah, A.; Clavier, N.; Lozano-rodriguez, M. J.; Szenknect, S.; Dacheux, N., Incorporation of thorium in the zircon structure type through the $\mathrm{Th}_{1-\mathrm{x}} \mathrm{Er}_{\mathrm{x}}\left(\mathrm{SiO}_{4}\right)_{1-\mathrm{x}}\left(\mathrm{PO}_{4}\right)_{\mathrm{x}}$ thorite-xenotime solid solution. Inorg. Chem. 2016, 55, 11273-11282.

(63) Knyazev, A. V.; Komshina, M. E.; Savushkin, I. A., Synthesis and high-temperature X-ray diffraction study of thorium orthosilicate. Radiochemistry 2017, 59, 225-228.

(64) Estevenon, P.; Welcomme, E.; Szenknect, S.; Mesbah, A.; Moisy, P.; Poinssot, C.; Dacheux, N., Multiparametric study of the synthesis of $\mathrm{ThSiO}_{4}$ under hydrothermal conditions. Inorg. Chem. 2018, 57, 9393-9402.

(65) Estevenon, P.; Welcomme, E.; Szenknect, S.; Mesbah, A.; Moisy, P.; Poinssot, C.; Dacheux, N., Impact of carbonate ions on the synthesis of $\mathrm{ThSiO}_{4}$ under hydrothermal conditions. Inorg. Chem. 2018, 57, 12398-12408.

(66) Fuchs, L. H.; Hoekstra, H. R., The preparation and properties of uranium(IV) silicates. The Am. Mineral. 1959, 44, 1057-1063.
(67) Hoekstra, H. R.; Fuchs, L. H., Synthesis of coffinite - $\mathrm{USiO}_{4}$ Science 1956, 123, 105.

(68) Mulak, J., Crystal field parameters in $\mathrm{USiO}_{4}$, from temperature dependence of paramagnetic susceptibility. J. Solid State Chem. 1977, $21,117-126$

(69) Deditius, A. P.; Pointeau, V.; Zhang, J. M.; Ewing, R. C., Formation of nanoscale Th-coffinite. Am. Mineral. 2012, 97, 681-693. (70) Deditius, A. P.; Utsunomiya, S.; Pointeau, V.; Ewing, R. C., Precipitation and alteration of coffinite $\left(\mathrm{USiO}_{4} \cdot \mathrm{nH}_{2} \mathrm{O}\right)$ in the presence of apatite. Eur. J. Mineral. 2010, 22, 75-88.

(71) Lian, J.; Zhang, J. M.; Pointeau, V.; Zhang, F. X.; Lang, M.; Lu, F. Y.; Poinssot, C.; Ewing, R. C., Response of synthetic coffinite to energetic ion beam irradiation. J. Nucl. Mater. 2009, 393, 481-486.

(72) Pointeau, V.; Deditius, A. P.; Miserque, F.; Renock, D.; Becker, U.; Zhang, J.; Clavier, N.; Dacheux, N.; Poinssot, C.; Ewing, R. C., Synthesis and characterization of coffinite. J. Nucl. Mater. 2009, 393, 449-458.

(73) Zhang, F. X.; Pointeau, V.; Shuller, L. C.; Reaman, D. M.; Lang, M.; Zhenxian, L.; Hu, J.; Panero, W. R.; Becker, U.; Poinssot, C.; Ewing, R. C., Structural transitions and electron transfer in coffinite, $\mathrm{USiO}_{4}$, at high pressure. Am. Mineral. 2009, 94, 916-920.

(74) Zhang, J. M.; Lu, F. Y.; Pointeau, V.; Zhang, F. X.; Lang, M.; Poinssot, C.; Lian, J.; Ewing, R. C., Irradiation effects of synthetic coffinite $\left(\mathrm{USiO}_{4}\right)$ studied by in-situ TEM. Mater. Res. Soc. Symp. Proc. 2009, 1193, 9-14.

(75) Reynolds, H. S. Synthesis, characterisation and dissolution studies of the uranium mineral coffinite. PhD. Thesis. Royal Melbourne Institute of Technology University, Melbourne, Australia, 2013.

(76) Mesbah, A.; Szenknect, S.; Clavier, N.; Lozano-Rodriguez, J.; Poinssot, C.; Den Auwer, C.; Ewing, R. C.; Dacheux, N., Coffinite, $\mathrm{USiO}_{4}$, is abundant in nature: so why is it so difficult to synthesize? Inorg. Chem. 2015, 54, 6687-6696.

(77) Calas, G.; Galoisy, L.; Menguy, N.; Jollivet, P.; Gin, S., Incipient formation of zircon and hafnon during glass alteration at $90^{\circ}$ C. J. Am. Ceram. Soc. 2019, 102, 3123-3128.

(78) Frontera, C.; Rodriguez-Carvajal, J., FullProf as a new tool for flipping ratio analysis. Phys. B 2003, 335, 219-222.

(79) Frondel, C., Hydroxyl substitution in thorite and zircon. United State Departement of the Interior Geological Survey 1953, Trace Elements Investigation Report 327.

(80) Dawson, P.; Hargreave, M. M.; Wilkinson, G. R., The vibrational spectrum of zircon $\left(\mathrm{ZrSiO}_{4}\right)$. J. Phys. C: Solid State Phys. 1971, 4, 240-256.

(81) Nicola, J. H.; Rutt, H. N., A comparative study of zircon $\left(\mathrm{ZrSiO}_{4}\right)$ and hafnon $\left(\mathrm{HfSiO}_{4}\right)$ Raman spectra. J. Phys. C: Solid State Phys. 1974, 7, 1381-1386.

(82) Caruba, R.; Baumer, A.; Hartman, P., Crystal growth of synthetic zircon round natural seeds. J. Cryst. Growth 1988, 88, 297302 . 
FOR TABLE OF CONTENTS USE ONLY

\section{Soft hydrothermal synthesis of hafnon, $\mathrm{HfSiO}_{4}$}

Paul Estevenon ${ }^{\dagger,+, \beta, \|, \text { Thibault Kaczmarek }}{ }^{\dagger, \ddagger}$, Mohamed Ruwaid Rafiuddin ${ }^{\ddagger}$, Eleonore Welcomme ${ }^{\dagger}$, Stephanie Szenknect ${ }^{\ddagger}$, Adel Mesbah ${ }^{\ddagger}$, Philippe Moisy ${ }^{\dagger}$, Christophe Poinssot ${ }^{\dagger}$, Nicolas Dacheux ${ }^{*}, \sharp$

${ }^{\dagger}$ CEA, DEN, DMRC, Univ Montpellier, Marcoule, France.

* ICSM, Univ Montpellier, CNRS, CEA, ENSCM, Marcoule, France.

$\S$ The European Synchrotron, CS40220, 38043 Grenoble Cedex 9, France.

" Helmholtz Zentrum Dresden-Rossendorf (HZDR), Institute of Resource Ecology, P.O. Box 510119, 01314, Dresden, Germany.

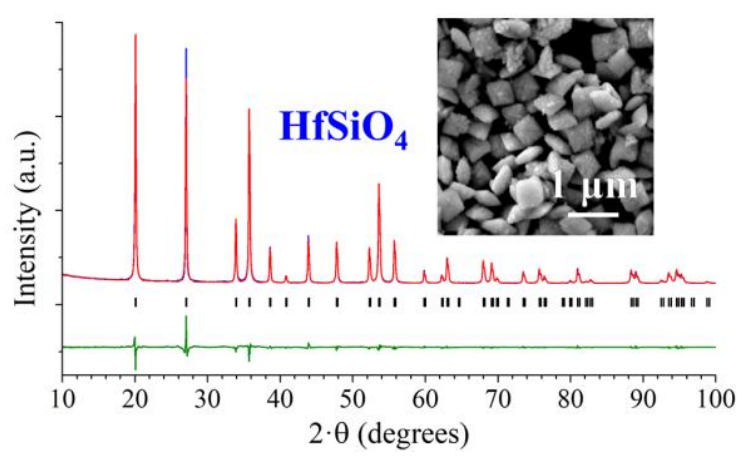

The conditions allowing the preparation of single phase $\mathrm{HfSiO}_{4}$ has been determined through a multiparametric study by varying the concentrations of the reactants, the $\mathrm{pH}$ of the reactive media or the temperature and duration of the hydrothermal treatment. $\mathrm{HfSiO}_{4}$ was prepared through relatively soft conditions $\left(\mathrm{pH} \leq 1.6, \mathrm{C}_{\mathrm{Si}} \approx \mathrm{C}_{\mathrm{Hf}} \geq 0.21 \mathrm{~mol} \cdot \mathrm{L}^{-1}, \mathrm{~T} \geq 150^{\circ} \mathrm{C}\right.$ for $\mathrm{t} \geq 24$ hours). 